\title{
Climate-Smart Initiatives in Sri Lankan Agriculture Sector: Experience and Perspectives in Solar Powered Water Pumping for Sustainable Crop Production
}

\author{
Bandara Rotawewa $^{1 *}$, Erandathie Lokupitiya ${ }^{2}$ \\ ${ }^{1}$ World Food Programme of the United Nation \\ Colombo, Sri Lanka \\ *Corresponding author's email: rotawewa [AT] yahoo.com \\ ${ }^{2}$ Department of Zoology and Environment Sciences, University of Colombo \\ Colombo, Sri Lanka \\ Email: Erandi [AT] sci.cmb.ac.lk
}

\begin{abstract}
The availability of low cost and long-lasting water pumping technology is a dream of every farmer. In Sri Lanka, fuel or electricity-powered water pumps are used to irrigate thousands of hectares of field crops, Vegetables, and fruits. Based on the International Water Management Institute (IWMI) survey conducted in the year 2000, there are about 50,000 agro-wells in the dry zone of Sri Lanka. More than 110,000 pumps are used to pump water from those wells. The fuel cost is the biggest burden for the farmers, which results in a high cost of production. The use of solar energy for water pumping is a promising alternative to conventional electricity and fuel-based water pumping systems. Solar-powered water pumping is based on photovoltaic (PV) technology that converts solar energy into electrical energy to run a DC or AC type water pump. This paper presents a comparative analysis of economic and environmental benefits associated with solar water pumping systems against fuel-based water pumping systems. The analyses were based on practical experience over 50 acres of land cultivated for export-oriented Green Cucumber by 100 members of Tempitiya Farmer Organization in Ampara District of Sri Lanka. It concluded that the solar water pumping system is advantageous compared to a fuel-based pump in terms of economic and environmental aspects.
\end{abstract}

Keywords—-solar energy; economic and environmental feasibility

\section{INTRODUCTION}

An Affordable and long-lasting water pumping system is a dream of every farmer. In Sri Lanka, Farmers use kerosene, diesel, or electricity-powered water pumps to irrigate Other Field Crops (OFC), vegetables, fruits and when necessary to irrigate paddy as a supplement to surface water irrigation. With lift irrigation, the cropping intensity is increased from 20 percent to 80 percent in YALA (dry) season. According to the International Water Management Institute (IWMI) survey in the year 2000, about 50000 agro-wells were used in the irrigation schemes in the dry zone of Sri Lanka with 110000 irrigation pumps. The report further states that the farmers had invested Sri Lankan Rupees (LKR) 0.8 billion on agro-wells and pumps (IWMI, 2003). The Food and Agriculture Organization of the United Nations (FAO, 2011) has suggested that there is a right way to fight poverty and stimulate the socio-economic improvement necessary to increase agricultural production which could be achieved by providing economic power for water pumping. It further states that sustainable agricultural intensification requires smarter and precision technologies for irrigation and farming practices that use ecosystem approaches to conserve water.

Solar water pumping is a reliable and economically attractive solution for off-grid irrigation and livestock water supply. It is one of the best alternatives for increasing dependence on water pumping for food security needs, and it could cut down the high cost of conventional energy sources used in water pumps by many communities. Development programs around the world have accelerated the market development for solar-powered water pumping systems, especially in developing countries. (Kunen et al, 2015)

A Photovoltaic (PV) cell converts sunlight directly into electricity and it is a commonly used technology particularly for sites that are far from the electricity distribution network in Sri Lanka (Ceylon Electricity Board, 2013).

Significantly lower carbon footprint and the potential environmental benefits from Solar Powered Irrigation System (SPIS) are inspiring, compared to conventional energy sources. (CEEW, 2013). The opportunity offered by solar irrigation for sustainable development, emissions reduction and climate resilience makes it a preferred nominee for climate financing (IREA, 2016). 
Solar-powered irrigation systems (SPIS) are not new to Sri Lanka. Sustainable Agriculture Water Management Project (SAWMP)" operated under the Ministry of Agriculture of Sri Lanka in 2005 introduced SPIS with a 150 Wp solar panel and a centrifugal pump. The daily average water discharge capacity was $6-7 \mathrm{~m} 3$ liters per day. The SAWMP project objectives were not achieved due to the low discharge rate, and the drip irrigation system adopted by the project. (Aheeyar et el, 2012).

Many researchers have compared the economic and environmental benefits of water pumping by different techniques. Hossain et al. studied the feasibility of the use of solar pumps for sustainable irrigation in Bangladesh and showed that solar pumps are profitable and more risk-free than diesel operated engine pumps. A study conducted by Rezae and Asghar on the technical and financial analysis of the water pumping system for Gorgan, Iran confirmed that the usage of solar energy causes a reduction in production costs during its operation. The economic viability of photovoltaic water pumping systems over the diesel-powered energy in the desert of Tunisia was presented by Mahjoubi et at., 2003.

The policymakers and users are unaware of the economic and environmental feasibility and technical suitability of SPIS for different irrigation water demands (Hossain et al. 2015). To discover the feasibility of the new technology, it is essential to know whether the technology is economically, environmentally and socially viable or not. Given the prevailing situation, FAO Sri Lanka aimed at introducing a solar energy powered water pumping system to demonstrate this new technology as a sustainable option under the project European Union Support to District Development Program (EU-SDDP) during 2013 - 2018. Therefore, this study evaluates the economic, environmental and technical feasibility of the use of solar-powered water pumps compared to the diesel-powered pumps for irrigation.

The FAO Action "Poverty Reduction through Agricultural Development (GCP/SRL/062/EC)" was implemented under the European Union - Support to District Development Program (EU-SDDP). The overall objective of the FAO Action was to contribute to poverty reduction through agricultural development and the provision of basic infrastructure and services of agriculture for vulnerable populations in the project areas of Sri Lanka.

FAO provided a series of coordinated income generation activities to vulnerable communities engaged in agriculture, fisheries and livestock to help them to initiate/ restart or expand their livelihoods.

A large extent of land in the Tempitiya village in Maha Oya Divisional Secretary Division of Ampara District of Sri Lanka was cultivated under rain-fed conditions. These lands situated along the Mundeniaru river were mostly underutilized except for practicing rain-fed paddy cultivation in Maha (rainy) season. FAO - Sri Lanka under EU-SDDP facilitated a contract-farming model with 100 farmers to an extent of 50 acres with reliable water supply to demonstrate the potential use of these lands for intensive agriculture through lift irrigation, which could benefit the vulnerable community living in the area.

\section{SITE AND METHODOLOGY}

The project location is in the Ampara District of Sri Lanka (latitude $7.612344^{\circ}$ and longitude $81.404630^{\circ}$ ) as shown in figure 1 . The climate is characterized by high temperatures ranging from $23^{\circ} \mathrm{C}$ to $39^{\circ} \mathrm{C}$. The area receives most of the rainfall during the northeast monsoon from early October to late January. The average annual dependable rainfall is 1,100 $\mathrm{mm}$. The May, July, August and September are relatively the driest months, and it does not receive at least $25 \mathrm{~mm}$ of rainfall (Met. Dept. of Sri Lanka, 2018). The rainfall pattern of this area is somewhat uni-modal indicating that farmers cannot cultivate during Yala (dry) season without a supplementary water source. 


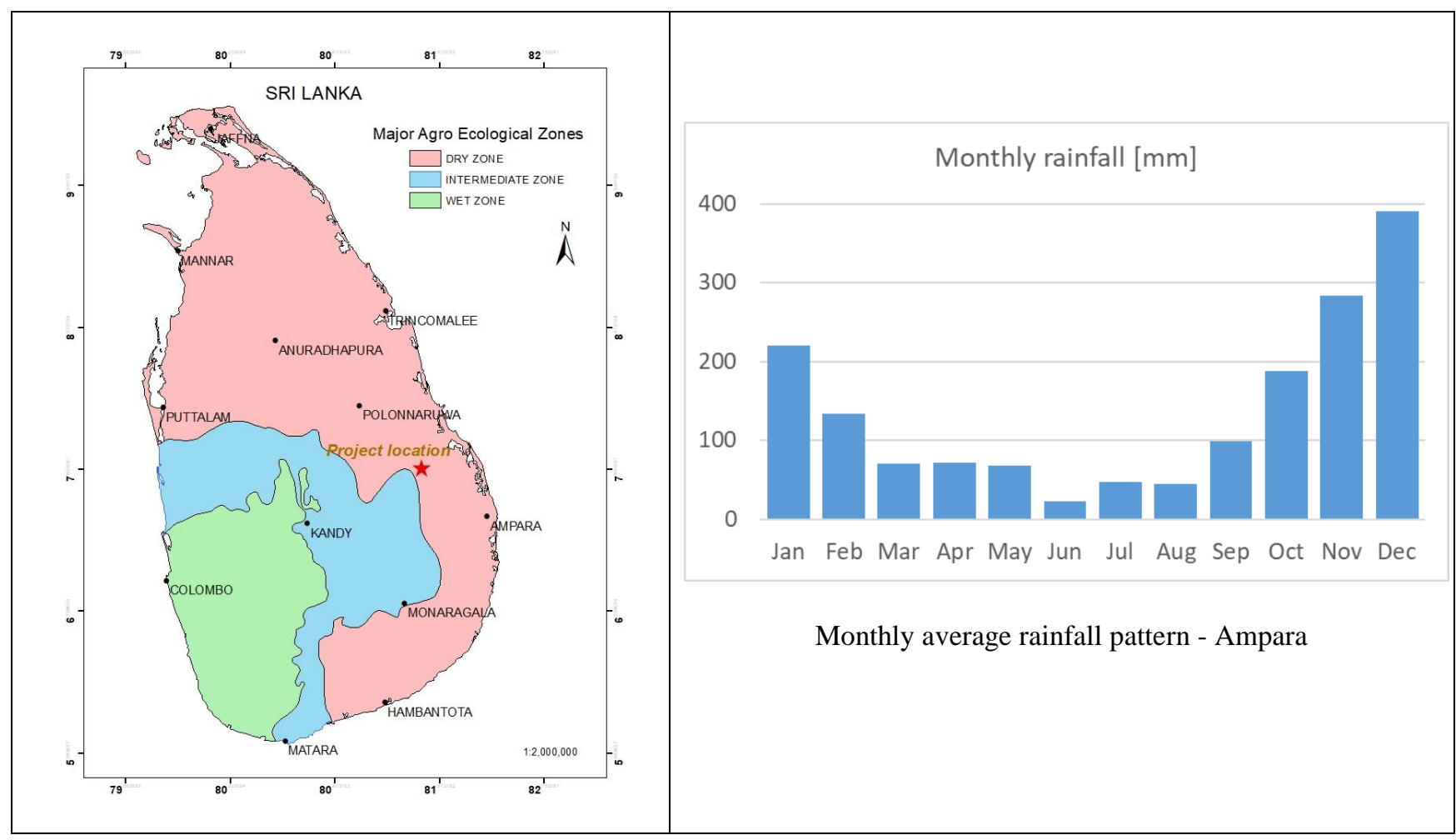

Figure 1: Project location (right) and monthly average rainfall pattern (left) Source: (Meteorology Department of Sri Lanka)

A contract farming model was introduced for 100 farmers in Tempitiya village, who had formed a Farmer Organization (FO). Further to that, they signed the contract-farming agreement with an agribusiness company to produce Green Cucumber for the export market.

Green cucumber is a cucumber species used for making pickles in brine vinegar. The crop cycle is 70 days. According to the climate in the area, green cucumber can be grown from February to the end of October. Therefore, during these nine months, three crop cycles can be cultivated. November, December and January are off seasonal months due to high rainfall. There is a fallow period of about 20 days in between two cropping cycles.

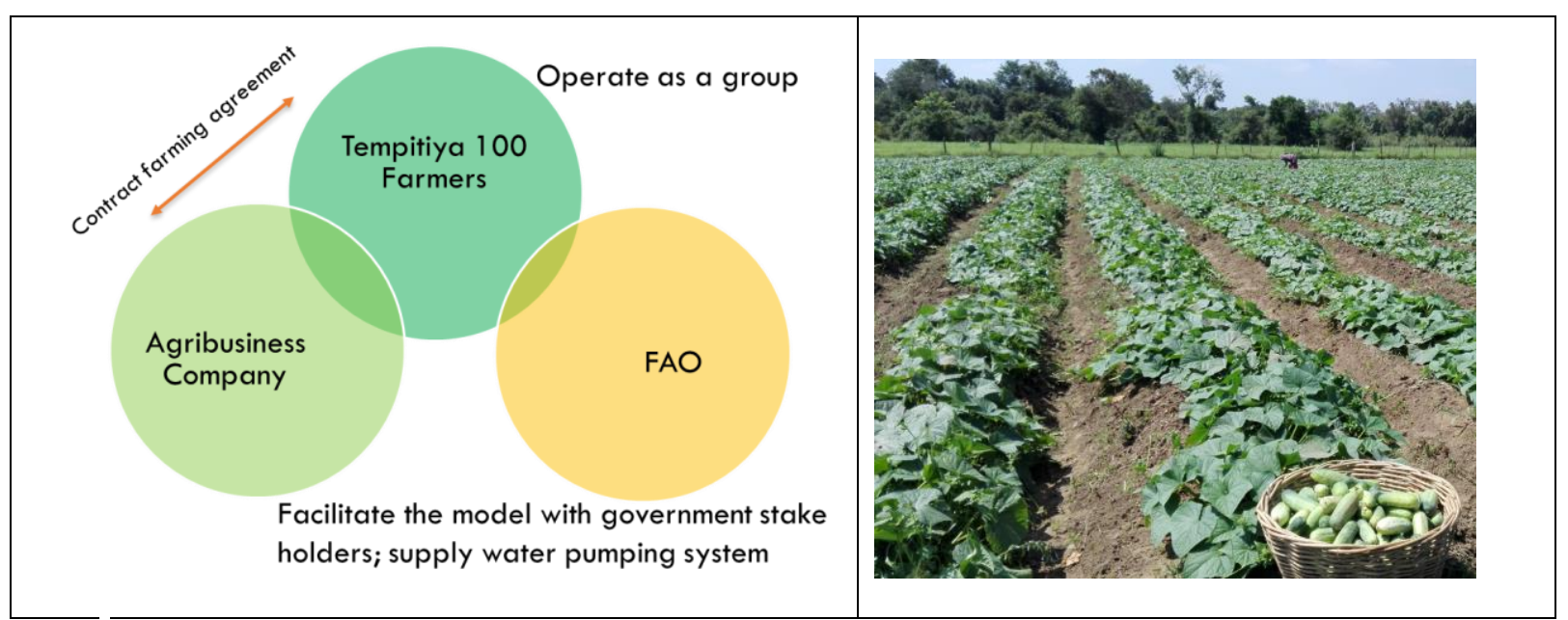

Figure 2: Contract farming model and green cucumber planted on ridges (left) Source: Own elaboration based on the project concept

Initially, the project had decided to install a diesel-powered water pumping system which consists of two $46 \mathrm{hp}$ diesel-powered engines to be installed at each agro well. The water conveying system (i.e. 4-inch pipeline) was designed for water distribution. The diesel requirement per hour per diesel pump was 10.5 liters. Therefore, the total daily diesel requirement was estimated as 168 liters for 8 hours of operation at the rate of LKR 95 per liter, which is the current market price. The Cost-Benefit Analysis (CBA) revealed that the fuel cost was a significant burden for the farmers. Kikuchi, 2003; Sieglinde Fuller, 2016). Additionally, the transportation of diesel and operation and maintenance of the 
system were very challenging tasks for the rural farmers. Therefore, the success of the use of solar-powered water pumping was evaluated as an alternative. Table 1 compares the characteristics of the solar- and diesel-powered water pumping systems.

Table 1: Characteristics of the solar and diesel-powered water pumping systems

\begin{tabular}{|c|c|c|}
\hline Items & $\begin{array}{l}\text { Diesel-powered water pumping } \\
\text { system }\end{array}$ & Solar-powered water pumping system \\
\hline Structure & & \\
\hline System & $\begin{array}{l}\text { Two } 46 \text { hp diesel engines, two pump } \\
\text { houses, water conveying pipelines, two } \\
\text { agro-wells }\end{array}$ & $\begin{array}{l}\text { Four } 7,920 \mathrm{Wp} \mathrm{PV} \text { arrays, four submersible } \\
\text { pumps, water conveying pipelines, two agro } \\
\text { wells }\end{array}$ \\
\hline Discharge & $600 \mathrm{~m}^{3}$ per day per pump & $300 \mathrm{~m}^{3}$ per day per pump \\
\hline & (total discharge $=1200 \mathrm{~m}^{3}$ per day) & (total discharge $=1200 \mathrm{~m}^{3}$ per day) \\
\hline Fuel consumption & $\begin{array}{l}10.5 \text { liters per hour per pump. (168 liters } \\
\text { per day totally) }\end{array}$ & None \\
\hline $\begin{array}{l}\text { Pump operational } \\
\text { schedule }\end{array}$ & $\begin{array}{l}50 \text { days per season } * 8 \text { hours per day } * 3 \\
\text { cropping seasons per year with adjustment } \\
\text { to rain }\end{array}$ & $\begin{array}{l}70 \text { days per season } * 9 \text { hours per day } * 3 \\
\text { cropping seasons per year with adjustment to } \\
\text { rain }\end{array}$ \\
\hline Life (years) & 15 years with two engine overhauls & Panel 15 years and two pump replacements \\
\hline Initial cost & LKR 16.2 million (US\$ 107,900$)$ & LKR 18. 1 million (US\$120,833) \\
\hline Field & \multicolumn{2}{|c|}{$\begin{array}{l}\text { 50-acre extent; crops: vegetables / other field crops (OFC); distance to be pumped: } 500-600 \\
\text { m mainline and secondary lines, pumping head: } 5 \text { m maximum }\end{array}$} \\
\hline
\end{tabular}

\subsection{Economic feasibility analysis}

This analysis aimed to compare the economic sustainability between a solar-powered water pumping system and a diesel-powered water pumping system. In this study, the economic analysis of the two systems was carried out using the following indicators.

Life cycle cost analysis (LCCA): Lowest life-cycle cost analysis (LCCA) is the most straightforward and easy-tointerpret measure of economic evaluation. LCCA takes in to account all the costs including initial capital cost, fuel cost, operation and maintenance expenditure, and replacement cost. In this study, the following formula was applied to calculate LCCA (Narale et al 2014):

$\mathrm{LCC}=\mathrm{CC}+\mathrm{MC}+\mathrm{FC}+\mathrm{RC}$

$\mathrm{CC}=\mathrm{Capital}$ cost (The $\mathrm{CC}$ is the initial capital expense for equipment, system design, engineering, and installation, etc.)

$\mathrm{MC}=$ Maintenance cost (Non-fuel operating costs, and maintenance costs)

$\mathrm{FC}=$ Fuel cost $(\mathrm{FC}$ of the system is the sum of the 15-yearly diesel cost)

$\mathrm{RC}=$ Replacement cost $(\mathrm{RC}$ is the sum of all repair and equipment replacement cost anticipated over the 15 -year life of the system)

Cost-benefit analysis (CBA): CBA is a tool to evaluate an investment decision to assess the community welfare change attributable to the investment. The purpose of a CBA is to facilitate the efficient allocation of resources (Sieglinde Fuller., 2016). 
The cost of a unit of water pumped out by the diesel pump was calculated: this value was taken to calculate the income from Diesel Powered Irrigations Systems (DPIS) and Solar Powered Irrigation System (SPIS). Furthermore, the additional revenue from electricity generation was added to the income of the SPIS. The possible monthly electricity generation days are tabulated in Table 2.

Table 2: Monthly irrigation requirement based on the season and rainfall, fuel requirement and days available for electricity generation

\begin{tabular}{|l|c|c|c|c|}
\hline Month & $\begin{array}{c}\text { Monthly irrigation } \\
\text { requirement as a } \\
\text { percentage based on } \\
\text { rainfall (A) }\end{array}$ & $\begin{array}{l}\text { Diesel pump } \\
\text { operating days } \\
\text { based on } \\
\text { irrigation } \\
\text { schedule (5 days } \\
\text { per week) (B) }\end{array}$ & $\begin{array}{c}\text { Monthly fuel } \\
\text { requirement } \\
\text { (A x B x 10.5 liters } \\
\text { /hour /8 hour per day/ } \\
\text { 2 pumps) }\end{array}$ & $\begin{array}{l}\text { Electricity } \\
\text { generation days } \\
\text { in case of solar } \\
\text { system }\end{array}$ \\
\hline January & $0 \%$ & Off season & 0 & 31 \\
\hline February & $100 \%$ & 20 & 3,360 & 0 \\
\hline March & $100 \%$ & 20 & 3,360 & 0 \\
\hline April & $90 \%$ & 10 & 1,512 & 3 \\
\hline May & $90 \%$ & 20 & 3,024 & 3 \\
\hline June & $80 \%$ & 20 & 1,680 & 0 \\
\hline July & $100 \%$ & 10 & 3,360 & 0 \\
\hline August & $100 \%$ & 20 & 3,360 & 0 \\
\hline September & $100 \%$ & 20 & 672 & 19 \\
\hline October & $40 \%$ & 10 & 0 & 31 \\
\hline November & $0 \%$ & Off season & 0 & 3 \\
\hline December & $0 \%$ & Off season & & 3 \\
\hline
\end{tabular}

Source: Own elaboration based on monthly average rainfall.

The solar system can be used to generate electricity during the days when the system is not used for pumping water. This is especially possible during November, December, and January where no irrigation requirement due to high rainfall. (Table 2 and Figure 4). The optional income generation opportunity gleaned through grid electricity replacement is an added advantage of the solar system. The calculation was based on the days available for electricity generation when the system would not be used for water pumping assuming a part of the irrigation requirement is fulfilled by rain. The electricity generation can be carried out during the offseason as well. The buying rate of Sri Lanka (Ceylon) Electricity Board, LKR 22 per 1kWh of solar-powered electricity, was assumed in the estimation of the income generated in selling the solar electricity to the national grid. The diesel fuel requirement was also estimated based on the irrigation schedule (i.e. 5 days per week) and cropping season (Table 2). 


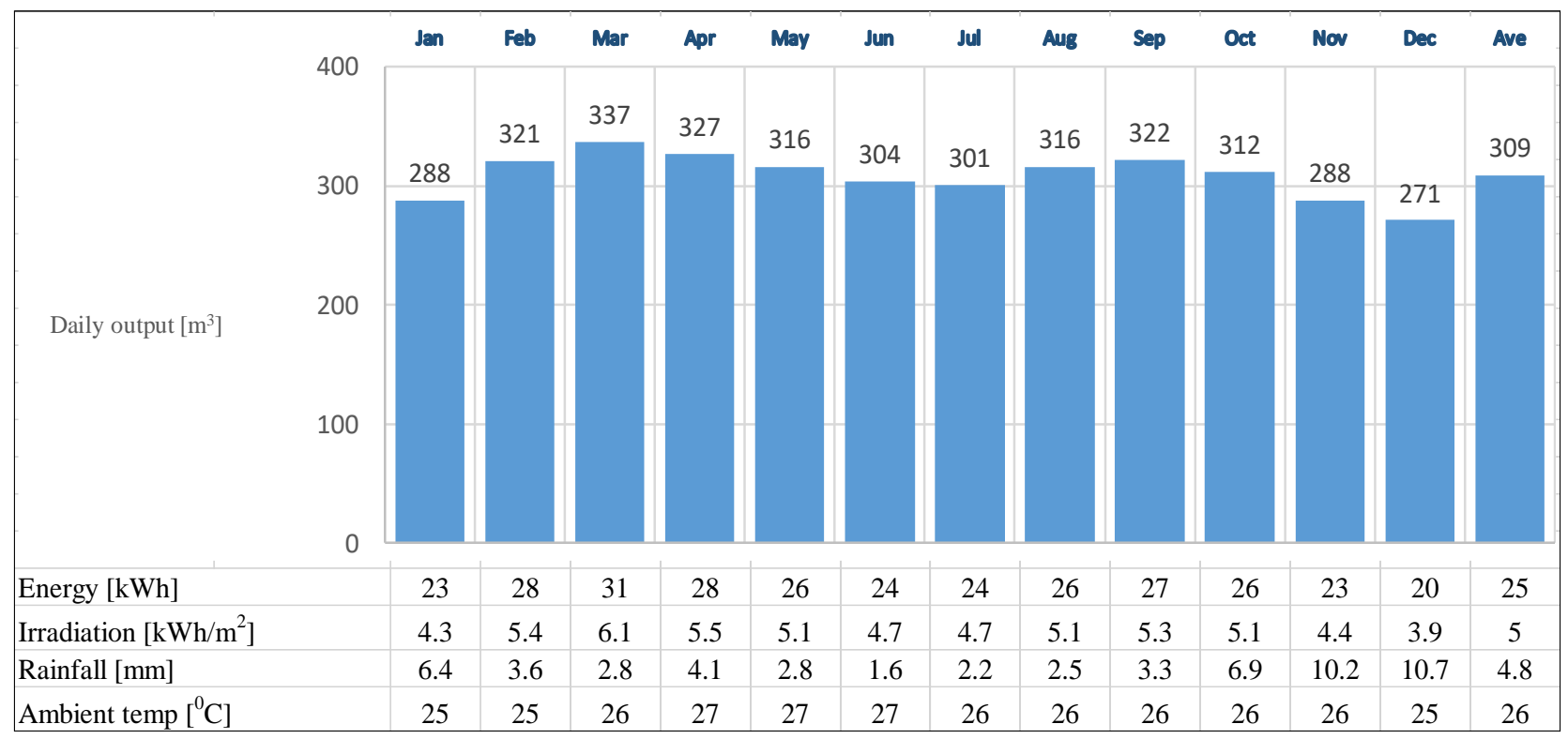

Figure 3: Daily values of output parameters of the solar-powered pumping systems. (Source: LORENTZ Solar quotation 2016)

Net present value (NPV): NVP estimates the current values of future cash flows over a period of time and it is $s$ an indication of the profitability of the investment. A positive NPV indicates the profitability of the investment and a negative NPV indicates the losses of the investment. In this study, Microsoft Excel NPV function was used with a 12 percent discount rate (Abu-Nowar, 2020).

Internal Rate of Return (IRR): IRR is the discount rate that makes the net present value (NPV) of the investment zero. Microsoft IRR function was used in this study. NPV and IRR could be used to decide between the alternatives in investment (Abu-Nowar, 2020).

\subsection{Environmental feasibility analysis}

Sri Lanka's per capita greenhouse gas (GHG) emission was $\sim 1.44$ tons of CO2eq in 2012. The Sri Lankan Government has been promoting the utilization of renewable energy sources that contribute to reducing GHG emissions. The agriculture sector accounts for $25 \%$ of the GHG emissions by Sri Lanka. Direct GHG emissions and emission offset due to solar electricity generation were estimated separately to ascertain the environmental benefits of the project.

An emission estimation was done using 2006 Intergovernmental Panel on Climate Change (IPCC) Revised Guidelines to study the GHG mitigation potential from the project. GHG emission from fuel consumption in the diesel pumping systems was calculated using the Tier 1 approach by the IPCC for stationary combustion. The emissions associated with the fuel transport were not taken into the calculation in this study.

Emissions $_{(\mathrm{GHG}, \text { fuel) }}=$ Fuel Consumption $_{(\text {fuel })} \bullet$ Emission Factor $_{(\mathrm{GHG}, \text { fuel })}$

Total GHG $\left(\right.$ in $\mathrm{tCO}_{2}$ eq $)=\left(\mathrm{CO}_{2}\right.$ emission $)+\left(\mathrm{CH}_{4}\right.$ emission $\left.* 21\right)+\left(\mathrm{N}_{2} \mathrm{O}\right.$ emission $\left.* 310\right)$

Where:

Emissions GHG ,fuel = emissions of a given GHG by type of fuel ( $\mathrm{kg} \mathrm{GHG)}$

Fuel Consumption. Fuel $=$ amount of fuel combusted $(\mathrm{TJ})$

Emission Factor GHG, fuel = default emission factor of a given GHG by type of fuel (kg gas/TJ).

Gross Calorific Value of diesel: 10,500 Kcal/kg (Ceylon Petroleum Cooperation).

21 and 310 are the global warming potential (GWP) of $\mathrm{CH}_{4}$ and $\mathrm{N}_{2} \mathrm{O}$, respectively (IPCC, 1995)

Greenhouse gas emission offset: GHG emission savings due to electricity production from solar cells was estimated using the following formula:

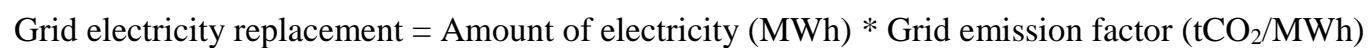

Emission Factor for National Grid: $0.7350\left[\mathrm{tCO}_{2} / \mathrm{MWh}\right]$ 


\section{RESULTS AND DISCUSSION}

\subsection{Economic feasibility}

Economic analysis indicators LCCA, CBA, NPV and IRR were used to compare the economic feasibility of SPIS and DPIS.

Life cycle cost analysis (LCCA): The LCC of SPIS was LKR 19.6 million while that of DPIS was estimated at LKR 50.4 million. Figure 5 shows the operating and maintenance cost components and the fuel cost of DPIS is higher than SPIS. Capital cost account for more than $90 \%$ of the life cycle cost of the SPIS. The capital cost (30\%) and fuel cost $(60 \%)$ contributed to the life cycle cost of DPIS. Further, fuel transport difficulties, the requirement of frequent site visits for refilling, starting up, and shutting down operations, and more extensive maintenance requirements specify the difficulties associated with DPIS.

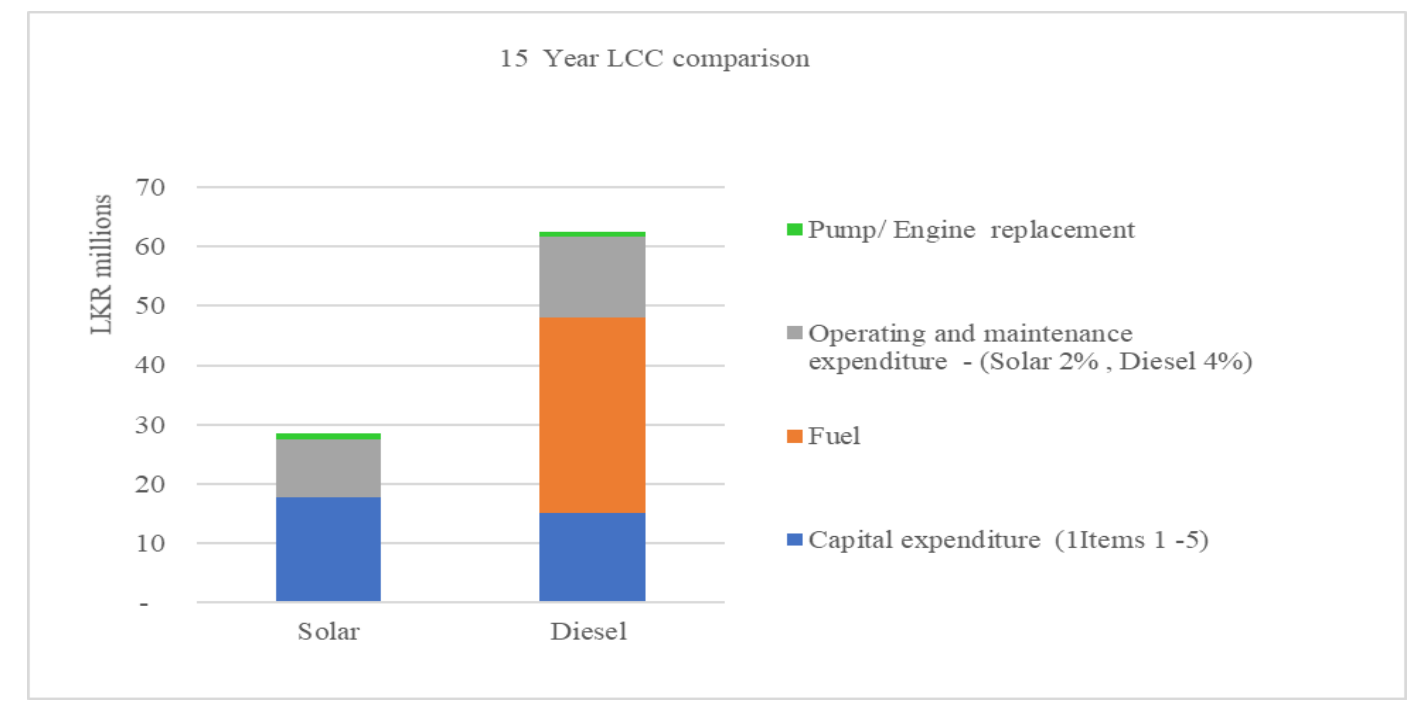

Figure 4: Cost comparison of solar and diesel-powered irrigation systems based on LCCA

Net Present Value (NPV): NPVs at $12 \%$ discount factor for SPIS and DPIS were estimated at LKR 15,151,047 and LKR 31,437,051 respectively. NPV of SPIS is higher than that of DPIS which indicates that investment in SPIS is more profitable than DPIS.

Internal Rate of Return (IRR): The IRR was estimated as 33\% and 9\% for SPIS and DPIS respectively, for 15 years of operation. The higher percentage of IRR for SPIS is due to the low cost associated with the irrigation using solar power.

The payback period is 4 years for SPIS, and the payback period is approximately $7-8$ years for DPIS (Figure 6).

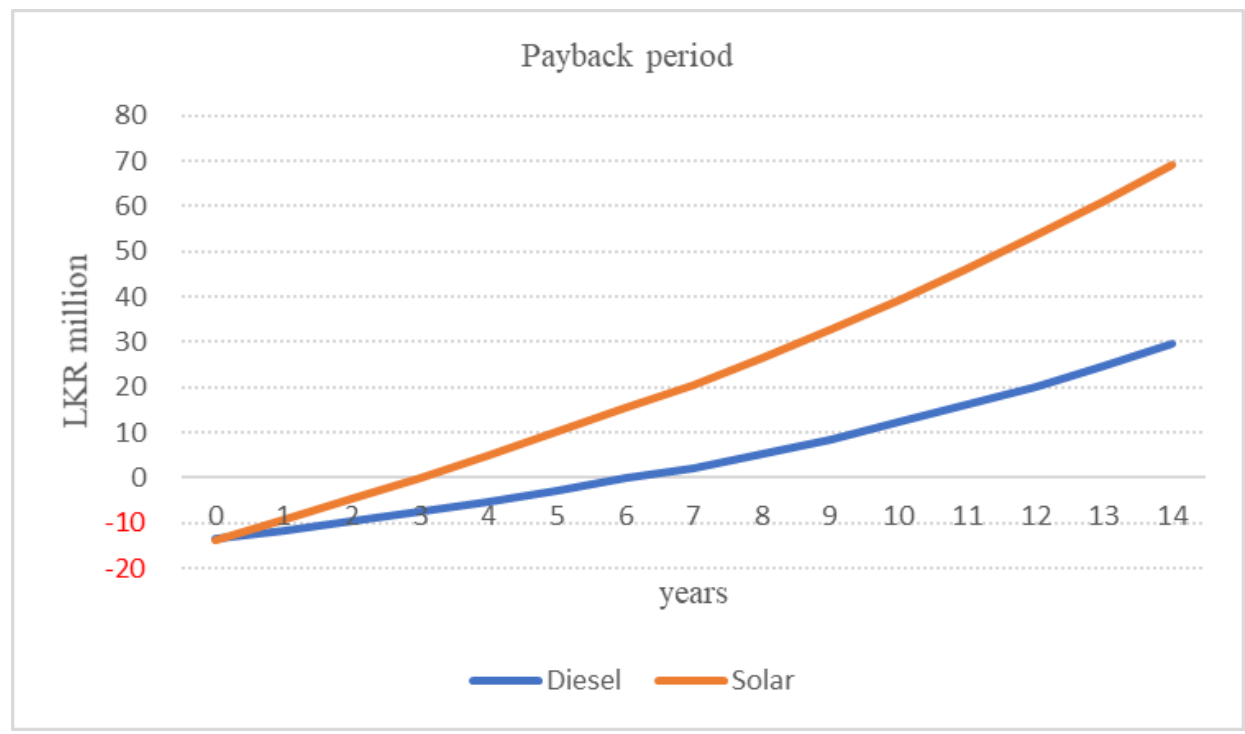

Figure 5: Payback period for SPIS and DPIS 
Cost-benefit analysis (CBA): The CBA provides evidence for the community on the profitability of SPIS compared to DPIS. The compulsory payment for operations and maintenance of SPIS is LKR 544 while it is LKR 5703 for DPIS. The cost of pumping $1 \mathrm{~m} 3$ of water from SPIS was estimated at LKR 8.50 and that of DPIS was estimated at LKR 18.50, which is twice higher compared to the SPIS. According to the CBA, the compulsory payment per month per farmer for operations and maintenance with reimbursement for capital expenditure for SPIS was LKR 1557 while that for DPIS was LKR 6572. These figures reveal that the SPIS is much more profitable for the community. The details relevant to the analysis are found in Table 3.

Table 3: Detailed Cost-Benefit Analysis for DPIS and SPIS

\begin{tabular}{|c|c|c|c|c|}
\hline \multicolumn{5}{|c|}{ Operations and Maintenance } \\
\hline Item & Description & $\begin{array}{l}\text { Diesel } \\
(\text { LKR) }\end{array}$ & $\begin{array}{c}\text { Solar } \\
\text { (LKR) }\end{array}$ & Remarks \\
\hline 1 & $\begin{array}{l}\text { Fuel consumption (per hour }-10.5 \text { per pump } x \\
\text { Cost of fuel x eight hours of operation } x \text { two } \\
\text { pumps } \times 30 \text { days }=(10.5 \times 8 \times 95.00 \times 2 \times 30)\end{array}$ & 478,800 & None & $\begin{array}{l}\text { Nominal fuel consumption } \\
\text { @ } 3000 \mathrm{rpm} \text { for } 47 \mathrm{hp} \\
\text { engine }\end{array}$ \\
\hline 2 & Lubricant - 40SAE & 3,000 & None & From maintenance manual \\
\hline 3 & Operator@ rate LKR 1500 & 45,000 & 45,000 & Farmer Organization \\
\hline 4 & Add other valve, pipeline items for maintenance & 12,000 & 12,000 & $\begin{array}{l}\text { From maintenance } \\
\text { estimate }\end{array}$ \\
\hline 5 & Allow tools for maintenance & 3,000 & 3,000 & $\begin{array}{l}\text { From maintenance } \\
\text { estimate }\end{array}$ \\
\hline 6 & Allow for record keeping - hired person & 15,000 & 15,000 & Farmer Organization \\
\hline 7 & Allow service charge for the mechanic & 15,000 & None & From maintenance manual \\
\hline 8 & Other charges & 7,500 & 7,500 & Farmer Organization \\
\hline 9 & $\begin{array}{l}\text { Income from grid electricity replacement per } \\
\text { month }\end{array}$ & $\begin{array}{l}\text { No electricity } \\
\text { generation }\end{array}$ & $(19,076)$ & From calculation \\
\hline 10 & $\begin{array}{l}\text { Total system Operations and maintenance cost } \\
\text { per month }\end{array}$ & 579,300 & 63,424 & Item $9 \times 30$ days \\
\hline 11 & $\begin{array}{l}\text { System water supply per month }\left(\mathrm{m}^{3}\right) \text { for } 50 \\
\text { acres }\end{array}$ & 32,000 & 32,000 & required water supply \\
\hline 12 & Water cost $\left(\right.$ per $\left.\mathrm{m}^{3}\right)$ & 18 & 2 & Item 10 /item 12 \\
\hline A & $\begin{array}{l}\text { Compulsory payment per month per farmer for } \\
\text { operations and maintenance }\end{array}$ & 5,793 & 634 & Item $11 / 100$ farmers \\
\hline \multicolumn{5}{|c|}{ Capital Expenditure } \\
\hline Item & Description & Diesel (LKR) & Solar (LKR) & \\
\hline 13 & Pump cost & $3,200,000$ & $7,043,400$ & Lowest quotation \\
\hline 14 & pipe line cost & $7,500,000$ & $6,700,000$ & Lowest quotation \\
\hline 15 & Pump houses for diesel pumps & $1,200,000$ & 200,000 & Lowest quotation \\
\hline 16 & Agro well & $3,750,000$ & $3,750,000$ & Lowest quotation \\
\hline 17 & Major repairs & $1,820,000$ & $1,095,651$ & \\
\hline \multirow[t]{2}{*}{18} & Total capital & $17,470,000$ & $18,789,051$ & \\
\hline & Depreciation cost recovery per month & 97,056 & 104,384 & $\begin{array}{l}\text { Total capital cost for } 15 \\
\text { years }\end{array}$ \\
\hline \multirow[t]{2}{*}{ B } & $\begin{array}{l}\text { Compulsory payment per month per farmer for } \\
\text { depreciation ( } 100 \text { farmers) }\end{array}$ & 971 & 1,044 & \\
\hline & $\begin{array}{l}\text { Compulsory payment per month per farmer for } \\
\text { operations and maintenance }+ \text { depreciations (A } \\
+ \text { B) }\end{array}$ & 6,764 & 1,678 & \\
\hline
\end{tabular}


Strengths

- Pollution-free, and it is a green solution to mitigate $\mathrm{CO} 2$ emission

- No regular fuel cost or maintenance cost

- Cost for unit of water, depreciation and maintenance is lower than DPIS

- No fuel transport difficulties, the requirement of frequent site visits for refilling, starting up, and shutting down operations

- Easy operation and comparatively long product life cycle
Weaknesses

- Limited knowledge and interest on environmental feasibility

- Initial investment is high and still not affordable for smallholders and tenant farmers

- Limited awareness and capacity in all sectors of the value chain of SPIS in Sri Lankan context

- Technical skills and knowledge on operation and maintenance of SPIS still does not exist adequately in the rural areas of the country

\section{Opportunities}

- Free from fossil fuel dependency

- Favorable government policies towards renewable energy

- Continuous improvement of solar technology and cost of SPIS continues to drop, making SPIS economically viable and competitive

- Rural development and food security through sustainable agricultural production through improved access to water

- Electricity produced during off season can be sold or used for other purposes

- Potential for financial models and opportunities for technology dissemination

\subsection{Environmental feasibility}

Direct GHG emissions reduction was estimated in two ways: GHG emission from direct combustion of diesel fuel and GHG emission replacement due to electricity generation option.

Direct emission due to diesel combustion:

Annual total GHG emission

Total GHG emission over a 15-year life cycle

GHG emission reduction due to electricity production:

Annual electricity sold per single system

Annual electricity sold from 4 units

Annual emission reduction

Total emission reduction for 15 years

GHG saving during 15 years by shifting to SPIS:

Diesel combustion

Grid electricity replacement

Total

$$
\begin{aligned}
& =63.191 \mathrm{tCO} 2 \mathrm{eq} \\
& =947.87 \mathrm{tCO} 2 \mathrm{eq} \\
& =2.6 \mathrm{MWh} \\
& =10.40 \mathrm{MWh} \\
& =7.65 \mathrm{tCO} 2 \mathrm{eq} \\
& =115 \mathrm{tCO} 2 \mathrm{eq} \\
& =947.87 \mathrm{tCO} 2 \mathrm{eq} \\
& =115 \mathrm{tCO} 2 \mathrm{eq} \\
& =1062.6 \mathrm{tCO} 2 \mathrm{eq}
\end{aligned}
$$

Based on the above calculations, annual carbon dioxide emission form DPIS is $63.191 \mathrm{tCO} 2$ eq to supply $284,000 \mathrm{~m} 3$ of water for 50 acres of land to cultivate green cucumber. The total carbon dioxide emission from DPIS is 947.87 tCO2 eq within 15 years of lifecycle. The solar pump is pollution-free, and it is a green solution to mitigate $\mathrm{CO} 2$ emission from irrigation pumps powered by fossil fuel. In comparison to the DPIS, cultivating 50 acres of land for 15 years could save 1062.6 tCO2 eq emission to the atmosphere, as it operates with zero carbon footprint. In the Dry Zone of Sri Lanka, 110,000 of fuel or electricity powered irrigation pumps were reported in the year 2000 (IWMI, 2003, IRENA, 2016). The usage of solar pumps is limited in the country. With advanced solar pumping technology, Sri Lanka has a high potential to promote solar pumps for sustainable green agriculture.

\section{CONCLUSIONS}

The life cycle cost (LCCA) of SPIS was LKR 19.6 million while that of DPIS was estimated as LKR 50.4 million where the SPIS derived lower life cycle cost compared to DPIS due to zero fuel cost and lower maintenance and operational costs. The CBA analysis provided evidence on the community level appropriateness of SPIS compared to DPIS. NPV and IRR values of SPIS evidence the sound economic feasibility of the shift. Comparatively, DPIS recorded a 9\% IRR which was below the $12 \%$ discount rate. Consequently, the sustainability of DPIS was not guaranteed. It was 
estimated that 1062.6 tCO2 eq of GHGs can be offset by shifting from DPIS to SPIS, during a period of 15-years. Electricity produced during off season is an added advantage of the system.

Sri Lanka as a tropical country receives ample solar radiation throughout the year. Further, the Sri Lankan government has been promoting the use of solar energy as a renewable energy source to reduce pressure on imported fossil fuels.

Moreover, in Sri Lanka it is rather rare to find studies on the use of solar energy in water pumping. Therefore, this research is an eye-opener for researchers, policymakers, financiers and end-users to select options based on informed decisions to promote water pumping facilities for sustainable agricultural production.

\section{ACKNOWLEDGEMENT}

The authors express their appreciation to Food and Agriculture Organization of the United Nations of Sri Lanka. We would also like to thank Ms. Rohini Singarayer, Mr. Kapila Wickramsasinghe and Mr. Ranjith Pushpananda for their support.

\section{REFERENCES}

1. Abu-Nowar L.M., 2020. Economic and Financial Assessment of Solar-Powered Irrigation. Journal of Agricultural Science, 12(4), p.185. Available at: http://www.ccsenet.org/journal/index.php/jas/article/view/0/42217.

2. Aheeyar M., Bandara M.A.C.S., \& Padmajani, 2012. Assessment of Solar Powered Drip Irrigation Project Implemented by Ministry of Agriculture - Phase 1. 10.13140-2.1.4766.0167.

3. Alireza R., \& Gholamian S.A., 2013. Technical and Financial Analysis of Photovoltaic Water Pumping System for GORGAN, IRAN, International Journal on Cybernetics \& Informatics (IJCI) Vol.2, No.2, April 2013. Retrieved from https://www.idc online.com/technical references/pdfs/information_technology/Technical\%20and\%20Financial.pdf

4. Campana Pietro Elia., Alexander Olsson., Hailong Li \& Jinyue Yan.,2016. An economic analysis of photovoltaic water pumping irrigation systems, International Journal of Green Energy, 13:8, 831-839

5. Ceylon Electricity Board.,2013. Long Term Generation Expansion Plan 2015-2034, CEB - Sri Lanka, http://www.ceb.lk/index.php?aam_media=4464

6. Food and Agriculture Organization of the United Nations., 2011. Save and Grow: A Policy Maker's Guide to the Sustainable Intensification of Smallholder Crop Production. FAO, Rome, Italy.

7. Horrigan., Lee., Robert S., Lawrence., \& Polly Walker., 2002. How Sustainable Agriculture Can Address the Environmental and Human Health Harms of Industrial Agriculture. Environmental Health Perspectives. 110:5(May): 445-456.

8. Hossain M.A., Hassan., M.S., Mottalib M.A., \& et al. 2015. Int J Energy Environ Eng 6: 147. https://doi.org/10.1007/s40095-015-0162-4

9. Intergovernmental Panel on Climate Change (IPCC).,2006. Guidelines for National Greenhouse Gas Inventories, http://www.ipcc-nggip.iges.or.jp/public/2006gl/vol2.html

10. IPCC SAR WG1.,1996. Houghton, J.T.; Meira Filho, L.G.; Callander, B.A.; Harris, N.; Kattenberg, A., and Maskell, K. (ed.), Climate Change 1995: The Science of Climate Change, Contribution of Working Group I to the Second Assessment Report of the Intergovernmental Panel on Climate Change, Cambridge University Press, ISBN 0-521-564336 (pb: 0-521-56436-0) pdf.

11. International Renewable Energy Agency (IRENA)., 2016. Solar pumping for irrigation: Improving livelihoods and sustainability, International Renewable Energy Agency, Abu Dhabi, https://www.irena.org/-

/media/Files/IRENA/Agency/Publication/2016/IRENA_Solar_Pumping_for_Irrigation_2016.pdf

12. Kikuchi. M., Weligamage, P., Barker. R., Samad M., Kono H., Somaratne H.M., 2003. Agrowell

and pump diffusion in the dry zone of Sri Lanka: Past trends, present status and

future prospects. Research Report 66. Colombo, Sri Lanka: International Water Management

Institute

13. Kunen E., Pandey B., Foster R., Holthaus J., Shrestha B., Ngetich B., 2015. Solar Water Pumping: Kenya and Nepal Market Acceleration. ISES Conference Proceedings, Solar World Congress, Daegu, Korea, p. 1-12.

14. Mahjoubi A., Mechlouch R., \& Ben Brahim A., 2010. Economic viability of photovoltaic water pumping systems in the desert of Tunisia. International Renewable Energy Congress November 5-7, 2010 - Sousse, Tunisia, IREC2010 - 39

15. Department of Meteorology., 2018. Climate of Sri Lanka. [online] Meteo.gov.lk. Available at:

http://www.meteo.gov.lk/index.php?option=com_content\&view=article\&id=94\&Itemid=310\&lang=en.

16. Narale P.D., Rathore N.S., \& Lad M.M., 2014. Techno-economic assessment of solar photovoltaic water pumping system. Internat. J. Agric. Engg., 7(1): 1-6. 
17. Rezae A., \& Gholamian S., 2013. Technical and Financial Analysis of Photovoltaic Water Pumping System for GORGAN, IRAN. International Journal on Cybernetics \& Informatics, 2(2), pp.21-31.

18. Sieglinde Fuller., 2016. LIFE-CYCLE COST ANALYSIS (LCCA), National Institute of Standards and Technology (NIST)https://www.wbdg.org/resources/life-cycle-cost-analysis-lcca

17. World Wildlife Fund \& Council of Energy, Environment and Waste., 2013. RE+: Renewables Beyond Electricity, WWF-India and CEEW, India, http://ceew.in/pdf/CEEW- 